\title{
23 \\ Legal Issues, an Overview on Co-Existence Policies: Technological Pluralism, Confidence Economy, Transnational Supply Chains
}

\author{
M.-A. Hermitte, S. Anvar, M. Bonin, N. Bargues, G. Canselier, \\ S. Desmoulin, A. Langlais, J.C. Varela
}

\subsection{INTRODUCTION}

Powerful scientific, industrial, agricultural, political and administrative lobbies have taken a stand in favour of GMOs. In opposition are numerous stakeholders, NGOs and networks, some more radical than others, that include scientists, farmers, consumers and some regional public authorities. Since 1998 those opposing GMOs have launched a series of actions such as destruction of GM crops and field trials, and some public authorities have made decisions to banish GM crops from a given territory. To varying degrees, it is clear that these are all illegal actions. Yet these illegal practices claim an element of legitimacy, based on public polls revealing year after year that a large portion of the general public are opposed to GM foods. This perennial convergence between small groups of activists and public opinion forced European and national public authorities to face a deep crisis of confidence. This crisis led to a decision to opt for a strategic change in the government of agricultural biotechnologies.

After a meeting of the European Environmental Council in 1999, a de facto moratorium was imposed on GMO approvals, thus opening up space to review the EU legal framework for biotechnologies. Activism against GM production, such as crop destruction, is primarily perceived as a serious legal offence, though some legal systems may treat this type of action as an act of civil disobedience. In addition, GMO-free zones are illegal under European law and, therefore, under national laws in their present form (Hermitte, 2006). However, the two combined phenomena, occurring over a long period of time, led the European Commission to seek a co-existence policy; a compromise between groups opposing and those favouring GMOs. The intent was to safeguard the sustainability of the three agricultural systems: the organic model (European Commission, 2007), the so-called conventional model and the transgenic, biotechnology-improved model. No agricultural option should be excluded from the Community. This solution is an attempt by European authorities to end the crisis generated by public distrust of GM food and feed.

In 2003 the European Union found the solution to resolve the situation, at least in theory. The Commission of European Communities (EC) published guidelines for a policy of co-existence between genetically modified (GM) and non-GM supply chains (European Commission 2003a). In three founding texts, the Commission sets out

Genetically Modified and Non-Genetically Modified Food Supply Chains: Co-Existence and Traceability, First Edition. Edited by Yves Bertheau. (c) 2013 Blackwell Publishing Ltd. Published 2013 by Blackwell Publishing Ltd. 
guiding principles for a project to segregate agri-food production, leaving Member States the responsibility of implementing these principles. This 'co-existence project' must be analysed as a new modality of a government of techniques (Levidow and Boschert, 2007). Faced with the difficulty of gaining the confidence of the general public, as well as that of some farmers, it was decided to leave free choice of whether to consume or produce organic, conventional or transgenic food and feed. This mode of government is particularly significant with regard to new and controversial technologies, which until now had been managed based only on potential or proven risks. The result is a 'government of techniques' that tends to prevent the involuntary spread of one technology, causing the elimination of other technologies. This choice of government could provide a means to meet the objective of technological pluralism, as seen with the 'energy mix'. Co-existence is also a new and more thorough expression of the freedom of trade and industry. ${ }^{1}$ To link the policy of co-existence to a freedom might seem paradoxical when we think about the tough constraints this model imposes on operators (see Section 23.1) $)^{2}$. Obviously, it is already difficult to organise such a model at the European level. Organising import supply chains from countries without the same priorities is even more complicated (see Sections 23.2 and 23.3). With these complications in mind, we will end our analysis with suggestions for a general liability system that is specially adapted to a controversial technology (Section 23.4).

\subsection{THE JURIDICAL NATURE OF CO-EXISTENCE POLICY}

\subsubsection{Co-existence and technological pluralism, a change in the relations between the 'rulers and the ruled'}

The idea that techniques need to be governed is a new idea for the modern era (Gottweis, 1998; Lezaun, 2006). It came about in an unplanned and casuistic manner, resulting from sanitary and environmental crises in various domains, risks associated with the pharmaceutical industry

\footnotetext{
${ }^{1}$ There is on-going research on mechanisms that are likely to be legally acceptable. One of the most interesting such mechanisms deals with the decision of several Appellations of Origin to ban GMO from animal feed.

${ }^{2}$ Co-Extra GM and non-GM supply chains: their CO-EXistence and TRAceability, Project Number 007158 Task 7.4.1 Deliverable D.7.21, The Juridical Nature of Co-existence Policy between GM and non-GM Supply Chains Technological Pluralism and Freedom of Trade and Industry.
}

and the nuclear realm and some technological developments inaccessible to private investments (such as space technology). Within the realm of genetic engineering, the idea of a necessary government emerged very early and has evolved rapidly over time: in 30 years, its 'constitution' has changed three times. Co-existence is its most recent expression.

The first mode of government to emerge can be referred to as a sort of alliance between administration, science and industry. 'The law of the Alliance' began with the Asilomar Moratorium in 1974 and ended with the adoption of Directive 90/220/EEC. Scientists, manufacturers and administrations coordinated their action and established a first set of guidelines applicable to contained use and later to the first experimental releases of GM products (Levidow et al., 2007). The first GMOs arriving into laboratories were already subject to regulations, something that was unprecedented historically. In fact, until this time, regulations emerged as a response to proven damage.

At this point, European authorities felt compelled to intervene in order to avoid segmentation of the European market into pro-GM and anti-GM laws. This is where Directive 90/220/EEC comes in: this second mode of government imposed a form of precaution specific to rulers. For the second time, there was a breakthrough in the legal history of government of techniques. The chosen options reflected mistrust towards a new mode of production, something which was never the case in the development of the energy, chemical or nuclear power sectors. ${ }^{3}$ Directive 90/220 EEC (and the regulation EC 258/97) represented a compromise between States, including those opposed to biotechnology and those that were more liberal or even indifferent (European Commission 1990; European Commission 1997). For Member States opposing GM technology, the directive provided the principle of authorisation for placing GMOs on the market with prior assessment of environmental and health risks. This was remarkable for a technique that had never been marketed before nor caused damage, and indicated a particularly strict implementation of the precautionary principle, not

\footnotetext{
${ }^{3}$ Here, we do not overlook reactions of resistance by workers deprived of work by a new machine or of reactions of fear towards high-speed trains. But these are only individual fears or fears of small isolated groups. What we have here is a legal text expressing actual mistrust of public authorities towards a new mode of production. This mistrust is not based on irrational fear but on the experience with other modes of production where lack of anticipation of the long-term consequences of technical choices invariably engenders damage.
} 
yet stabilised at this time. For manufacturers and Member States more favourable to GM technology, the directive granted the principle of a unique authorisation, valid for the entire European territory. The free movement of biotechnological products, an original principle of EEC, was thus ensured.

This directive was consistent with the framework of freedom of trade and industry, restricted by motives of public interest and protection of health and the environment. The freedom enjoyed by operators within the agroindustrial sector further down the line suggested that the legal framework adopted for GMOs was a liberalist one. Farmers and agro-food manufacturers could freely chose whether or not to use transgenic technology, without taking any specific preventive measures, apart from labelling some products. Yet, even without detailed knowledge of the mechanisms and expected quantities of admixture, the occurrence of gene flow between crops of the same type (e.g. from maize to maize) and between cultivated crops and wild relatives (e.g. from oilseed or rapeseed to wild radish) was roughly known, foreseeable and thus raised predictable issues.

With GMOs, there was generally a lack of anticipation of culture contamination problems, and stakes rapidly rose to a situation of conflict. In June 1999, the decision was made to stop granting marketing authorisation for GMOs, creating a de facto moratorium. Several reasons motivated this move: the desire to restore public and market confidence, the need to conceive a regime of liability and the need to implement identification, labelling and traceability of GMOs. The term 'co-existence' was not openly used, but the idea of imposing systems of labelling and traceability logically led to it. What ultimately justified the moratorium was the willingness to change the political and legal framework. This change brought about the third mode of government of techniques, known as 'technological pluralism' (Hermitte, 2007).

The breakthrough occurred in 2003 when, in three texts, European authorities completely overturned their mode of government. In the new legal framework, risk assessment was backed by a second step of agri-food production management. The preliminary assertion, that 'no form of agriculture, be it conventional, organic or agriculture using GMOs, should be excluded in the European Union', reflects a will to ensure technological pluralism, already present in domains such as the energy sector. The coexistence model shows positive outcomes that could be, at least, a more cautious approach toward new techniques and, at best, the reversibility of technical choices that have proven negative, long-term effects. The choice for co-existence was thus expressly stated as a compromise between opposing opinion groups, and no longer between opposing Member States (even though Member States played a major role in this choice). These opinion groups included conventional and organic farmers, their distributors, processing firms and consumers on one side, and GM distributors, their processing firms, farmers and consumers on the other.

What remains now is to examine the kinds of constraints imposed by implementing this new model, and the meaning of these constraints with respect to the freedom of trade and industry.

\subsubsection{Freedom of choice by operators as a more thorough expression of the freedom of trade and industry}

The traditional terms of freedom of trade and industry, conventionally implemented without special precautions to protect the technologies from one another, result in the most powerful technology excluding all others. An example of this was the twentieth-century choice of favouring a biochemical basis for agriculture. In contrast, 'technological pluralism' allows different technical options to co-exist in the name of freedom of choice for operators (or to protect public interest, for example, in the case of diversified energy sources). In principle, the purpose of free choice of production and consumption is straightforward. However, we see that this freedom translates into direct constraints on both non-GM and GM producers. Indeed, in the absence of appropriate intervention, the freedom of one group of producers impinges on the other's freedom. This is why constraints have been put in place.

The recommendation of 23 July 2003 is a text with no legal value, though it is taken into consideration by Member States (European Commission, 2003); recommendations are invitations to adopt rules of conduct. In principle, neither recommendations and opinions, nor resolutions and conclusions, have legal consequences. $\mathrm{cf}$. http://europa.eu/legislation_summaries/institutional_ affairs/decisionmaking_process/114535_en.htm). It refers mostly to farmers' capacity to freely choose between transgenic, organic or conventional agriculture (pt. 3 and Annex 1.1). The wording differs in the case of consumers, whose freedom of choice is ensured only indirectly through systems of labelling and traceability (by Regulation 258/97/EC, Directive 2001/18/EEC and Regulations 1829/03/EC as well as 1830/03/EC; (European Commission 2001; European Commission 2003b; European Commission 2003c). Freedom of choice is therefore clearly 
stated and ensured for farmers, but not for consumers. The Commission proposed the co-existence principle, as well as national implementation guidelines, but Member States have to frame their policy in accordance with the specifics of their agriculture. Thus, the proposed legislations differ greatly among Member States (European Commission, 2009).

National co-existence strategies should ensure an equitable balance between the interests of farmers of each production type; this stands out as a general principle. However, the text stipulates that 'during the phase of introduction of a new production type in a region, operators who introduce the new production type should bear the responsibility of implementing the farm management measures necessary to limit gene flow'. The acceptable limits are not specified. In other words, at the farm level, GM farmers must bear the costs of management measures to protect non-GM farms (e.g. isolation distances). No mention, though, is made of the probably much larger costs incurred by non-GM farmers to have their production identified and controlled, and this cost burden issue is not analysed. The Commission recommends that Member States establish a Land Register to keep track of the exact location of GM-fields and thus to monitor production patterns on a seasonal basis, to help in building coordination between neighbouring farms and to identify responsibilities in case of adventitious GM presence above the legal threshold. In parallel, the GMO notifiers have to provide the EC with general and specific surveillance plans that include detection of foreseeable or unforeseen human, animal and environmental health issues.

Running a farm according to one's own choice - organic, conventional or transgenic production - certainly conforms to the freedom of trade and industry as outlined in the Rome Treaty and by the World Trade Organization (WTO). However, this freedom entails high levels of constraint for all producers: constraints are necessary in order to ensure freedom of choice in agriculture.

Co-existence materialises at every step of production. It impacts on seed producers, farmers at the field level (who must keep minimum isolation distances from their non-GM neighbours and beekeepers, create buffer zones, pollen traps, manage field borders, clean farm and particularly shared equipment, create controls, inform public authorities, neighbours, and the public), transporters, storage cooperatives or companies, grain traders and processors via traceability, and distributors via labelling. The situation of a non-GM farmer seems less constrained at first glance, but it involves juridical risks if the contamination threshold is exceeded. Under Regulation 1829/2003/EC, non-GM farmers are not required to label their crop as 'GM' using the official mandatory terminology, provided that the presence of GMOs is fortuitous or technically unavoidable and below the $0.9 \%$ threshold, calculated using a DNA unit (this calculation method can greatly affect co-existence possibilities when using stacked-gene GMOs; European Commission recommendation on technical guidance of sampling and detection of GMO (2004)). If crops are contaminated beyond this threshold and if this contamination is not detected, products will be marketed without proper labelling. Non-GM farmers will face criminal charges for misleading advertising and fraud. The absence of GM labelling therefore involves a high risk to farmers who do not conform to the legislation, via potential prosecution under criminal laws of individual Member States. The farmers must prove, through their quality assurance system, that fault for contamination lies with a provider. A question is therefore raised: who should support the costs associated with control procedures?

The agro-industrial sector also faces high levels of constraints, particularly in order to label products consisting of over $0.9 \%$ genetically modified material. This implies important traceability monitoring and control costs at every stage, from production to distribution. ${ }^{4}$ Also, public authorities have their share of complications, as noted by Y. Bertheau and J. Davison (2007). Vast and costly research programmes have been undertaken in order to help develop norms for implementing controls on the co-existence project. The results of these research projects can be used in other food and feed sectors with safety or quality thresholds.

The constraints imposed by the co-existence project are so great that one tends to see them as hindrances to the freedom of trade and industry. On the contrary, the intention is to reach a balanced expression of freedoms. In fact, evidence from foreign cases strongly suggests that non-GM farmers' fields invariably end up contaminated when no regulatory protections exist. Stewardship rules established by seed producers are not sufficient, ${ }^{5}$ as exemplified by the

\footnotetext{
${ }^{4}$ The costs of such accidents are enormous, as exemplified with StarLink Maize and more recently with L1 Rice 601, Commission Decision of 6 November 2006 amending Decision 2006/601/EC on emergency measures regarding the nonauthorised genetically modified organism LL RICE 601 in rice products OJEC n ${ }^{\circ} \mathrm{L} 306,07 / 11 / 2006$ p.17.

5 cf. Press release of Percy Schmeiser March 19, 2008: 'Monsanto reconnaît une contamination des champs de Percy Schmeiser et fait une transaction' (It is the second case P.Schmeiser, Monsanto)
} 
Bt10 corn, LL601 rice and so on cases in the USA. ${ }^{6}$ The protection of everyone's freedom lies in the efforts made by the entire chain of actors. This freedom can be restricted on the basis of general interest considerations: personal security (e.g. withdrawal of dangerous products from the market), safeguarding public services operating as monopolies, management of professions (e.g. prior authorisations, requirement to hold specific degrees), natural resource management (e.g. fishing quotas) or market management (e.g. milk quotas). The public authorities thus protect an external interest. On the contrary, co-existence is founded on the freedom of choice for consumers and farmers. In this case, the issue is not the protection of an external interest through imposed restrictions on freedom, but the protection of parallel freedoms of a similar nature.

The debate is thus based on a different framework, technological pluralism as a new preferred model. It is worth noting that, in its classical interpretation, the freedom of trade and industry undermines technological options that some actors would have liked to maintain. As a general rule, there is a conflict between technological options that are each vying for the upper hand over all others. Numerous weapons are used in this war: superiority of a technology based on consumers' needs or desires (e.g. digital technology), planned elimination of an older technology by the most powerful groups in order to sell the new patented products and normalisation procedures. State subsidies can play a role: for example some agricultural subsidies are only granted if farmers use certified seeds rather than farm-saved seeds.

This change of perspective results from public intervention in decision-making processes. It lies, too, in a change of decision-makers' attitudes towards technical progress. Progress is seen less as a linear mechanism where new replaces old, and more as a necessary proliferation of distinct models. The idea of technological pluralism is fragile and is not sufficient for organising co-existence if the elements necessary to its sustainability, such as the opportunity to produce GMO-free seeds, are not in place: seeds with a very low rate of fortuitous presence are thus needed. In addition, it is indeed necessary to pursue specific research for genetic progress adapted to both organic and conventional agriculture needs (Meynard and Jeuffroy, 2006), and to dispose of non-transgenic plant

\footnotetext{
${ }^{6}$ http://gmoglobalconference.jrc.ec.europa.eu/2008/ Presentations/Waiblinger\%20-\%20Sampling $\% 20$ non-authorized $\% 20 \mathrm{GMO} \% 201$ low $\% 20$ levels $\% 20 \% 20$ Waiblinger\%20250608\%2012\%2030.pdf.
}

varieties that can effectively compete with transgenic varieties.

In order to understand the main issues, one must particularly examine the technological and commercial locking mechanisms which structure the economical and technological choices of companies. The two main constraints that limit companies' technological choices are the availability of seeds and the issues concerning labelling.

\subsection{KEYPOINTS OF SUPPLY CHAIN STRUCTURING}

Without varietal improvement in GM and non-GM seeds, co-existence has no meaning. A simple break in research concerning either technology will be enough to result in the disappearance of co-existence within a few years due to a lack of agronomic performance. An interesting example can be observed in Brazil, where GM soybean was cultivated only after locally appropriate varieties were sold. Because agronomic performance depends on the genetic background of varieties, biotech companies have been forced to buy company seeds in order to get appropriate genotypes in which to integrate the biotech traits: if this non-GM genetic background is no longer available, technological pluralism will not be sustainable in the long run (see Section 23.2.1). The reason behind maintaining two approaches is to give free choice to both farmers and consumers: labelling and traceability are essential in order to construct this type of confidence economy (see Section 23.2.2).

\subsubsection{Seed issues, a challenge for sustainable technological pluralism}

Five points regarding seed issues must be considered: prevention of contamination of genetic resources, access to genes of interest, maintenance of research on non-GM varieties, levels for seed contamination and preservation of farm-saved seeds.

\subsubsection{In order to create a plant variety, whether by conventional means or by biotechnology, it is necessary to base improvement work on genetic resources}

If we wish to promote, or at least to permit, co-existence it is necessary to have a twofold policy of genetic resources. Some resources will serve to concentrate genes of interest introduced by transgenics; this can be easily achieved in research collections. Other genetic resources need to be protected from contamination, which is somewhat more difficult. All resources stocked in ex situ banks are protected from contamination, but they cannot provide all services expected from genetic resources because their 
quality is variable and because they are rather static and never complete, whatever their number. ${ }^{7}$ The living resources, whether they are in public or private collections or in the original centres of diversification, are exposed to pollen drift. These are the resources that must be protected with rigorous distance rules. This is particularly true in the centres of origin of cultivated plants (see: de Candolle, 1883; Vavilov, 1951; Harlan, 1987; Haudricourt and Hédin, 1987). Without protection, seed suppliers will no longer be able to produce non-transgenic varieties and introgress new natural traits, since their selection basis will already be transgenic:

Access to a range of genetic diversity is critical to the success of breeding programs. The global effort to assemble, document, and utilize these resources is enormous, and the genetic diversity in the collections is critical to the world's fight against hunger. The introgression of genes that reduced plant height and increased disease and viral resistance in wheat provided the foundation for the 'Green Revolution' and demonstrated the tremendous impact that genetic resources can have on production (Hoisington et al., 1999). ${ }^{8}$

However, at present, no international legal standard or convention takes this problem into account: everything is determined by national authorities. ${ }^{9}$ For example, in the case of contamination of Mexican wild corn varieties, which had been long denied but has now been confirmed, GM corn cultures had been unsuccessfully prohibited by the Mexican government. A recent Presidential Decree, dated 6 March 2009, authorised these cultures, immediately inciting a petition (Piñeyro-Nelson et al., 2009). ${ }^{10}$

${ }^{7}$ http://www.cgiar.org/; an initiative has been taken in this context: the Svalbard Global Seed Vault, a secure seed bank in Norway. The seed vault is a common initiative of the Norwegian Government, the Global Crop Diversity Trust and the Nordic Genetic Resource Center.

${ }^{8}$ This paper includes multiple examples of interesting genes found in wild or ancient populations. For example, the success story of salinity resistant Chinese wheat selected with ancient local resources, ancient resources from other parts of the world, CYMMIT and long cross-breeding. This was done in order to achieve significantly increased results in the North West of China, where soils are very spoiled due to salinity, http:// english.cas.ac.cn/eng2003/news/detailnewsb.asp?InfoNo= 27707.

${ }^{9}$ The FAO Treaty on phyto-genetic resources deals mainly with collection resources, and the Convention on Biological Diversity does not give particular importance to the centres of origin.
All countries and seed companies should contribute to protection of these centres of origin, as they are of collective interest. It is at least possible to state that collective 'services' provided by the centres of origin should be paid (according to the expression used by OECD, cf.ENV-EPOC-GSP-BIO(2008)6. The Convention on Biological Diversity tried to lay out the legal framework for marketing such services (cf. Bellivier F. and Noiville C., 2009).

\subsubsection{In order to perpetuate co-existence, public authorities should also pay attention to consequences of genes and vegetal varieties patentability}

According to the NGO 'ETC Group', BASF, Monsanto and Syngenta have submitted patent applications for more than 500 genes involved in resistance to climate change related events such as drought, flood and changes in salinity (Noisette, 2008; ETC Group, 2008). These genes, which have an obvious collective interest, may then no longer be used by competitors in transgenics. However, we do not know what the reaction of the patent holders would be if these genes were found in genetic resources, ex situ resources or in non-transgenic improved varieties obtained through conventional selection. If this were the case, patent holders may suspect counterfeiting. Indeed, laws on patents and on plant breeder's rights organise nonvolunteer licences in a number of circumstances of general interest, including food constraint. But it would certainly be preferable to anticipate and, at least, to include a clause in patent law that limits holders' rights to genes from transgenic varieties and not to those obtained through other plant improvement methods.

\subsubsection{Is there a future for the breeders of non- transgenic varieties?}

Breeders of non-transgenic varieties theoretically have the full advantage of co-existence as their market shares will not be automatically eroded by GMO contaminations. However, market share may not remain constant because the number of breeders of non-transgenic varieties has decreased enormously. Most of the non-transgenic breeders work in both domains, often with a preference for

\footnotetext{
${ }^{10}$ Alien genes escape into wild corn, New Scientist Magazine, 21 February 2009; Piñeyro-Nelson et al. 2009; cf. the explanation developed by L.Ceballos and B.Eddé: Contamination du maïs mexicain, la controverse scientifique, INF'OGM, November 2003 ; doi: 10.1111/j.1365-294X.2008.03993. Petition on transgenic corn culture in Mexico http://www.redendefensadelmaiz. org/.
} 
producing the transgenic varieties (which are more profitable because they are better protected). Yet, non-transgenic varieties are attractive to many farmers, due either to conviction or economic interest. This is clearly the case with US soybean farmers' renewed interest in non-transgenic varieties (10\% demand increase from 2006 to 2008). However, conventional soybean farmers have difficulty finding what they seek (The Organic \& Non-GMO Report March 2009, www.soybeanpremiums.org). This example demonstrates exactly how dangerous it is to let powerful companies such as Syngenta or Monsanto believe that they have a dominant technological position in the market, because prices soar very quickly. A policy of reversibility would be focused on limiting the dominance of any one company.

The question then turns to determining whether conventional varietal improvement is blocked by technological locks. This does not, however, seem to be the case. The examples of non-GM sulfonylurea herbicide-tolerant soybean and corn, obtained by Dupont de Nemours, deserve to be mentioned. They have not been the object of any special communication to the public, although they show the same advantages (and disadvantages) as their GM equivalents. ${ }^{11}$ More recently, a drought-tolerant conventional soya variety seems to be the object of greatest interest (Noisette, April 2009). However, little is known about the breeder's strategies regarding the non-transgenic method. In fact, public research has largely withdrawn from varietal improvement (with the exception of a few widely advertised research projects aimed at specific problems in developing countries). Co-existence should renew interest in conventional methods of varietal improvement.

\subsubsection{Under a policy of co-existence, seed producers must maintain very low levels of seed contamination}

A specific contamination threshold has not yet been fixed by European authorities, but the level for seeds must be lower than the level for finished products. This is a sensi-

\footnotetext{
${ }^{11}$ http://www2.dupont.com/Biotechnology/en_US/science_ knowledge/herbicide_resistance/herbicide_resistance.html. Industrial seed suppliers must also ensure identity purity, analytical purity, minimum germination and maximum moisture content; these conditions are of less interest to co-existence. The whole system is detailed in Co-Extra Deliverable 7.22.2. Compare differences between regulated species and nonregulated species, certified seeds (control throughout the whole production and commercial stages), commercial or standard seeds (only post-harvest controls).
}

tive problem for organic and contractually non-GM products, whose threshold is often fixed at $0.1 \%$. Industrial seed suppliers must ensure varietal purity. To satisfy minimum varietal purity rates, organic and non-GM supply chains and production areas are necessary, organised by a synergy between regulations and contractual freedom. Seed production areas are generally organised by seed producers and multipliers under the auspice and control of 'inter-profession'. The created 'islets' for corn, for example, are planted with varieties that are all pollinated by the same male, fertilising plant. Such dedicated areas can be created for GM, conventional and organic crops. Mapping is a key element in defining seed production areas. The land register system, linked to co-existence in general and foreseen in the EC recommendations, can facilitate this organisation even though its practical implementation is not obvious. But the constraints necessary to organise co-existence between GM and non-GM seeds are stricter than those between varieties of conventional seeds. The existing dedicated seed production areas, negotiated within the seed 'inter-profession', should be better protected. This will be difficult, given the constraints on neighbouring farmers. The lower the allowable admixture threshold, the higher the costs.

\subsubsection{A great difficulty with 'farm-saved seed production'}

Farm-saved seed production ${ }^{12}$ is a common activity among farmers $(93 \%$ do this for price reasons, $30 \%$ for quality reasons and $30 \%$ for reasons of freedom of choice). The Council Regulation of 27 July 1994 (European Commission, 1994) recognised this type of production as a right in the European Union for some species, though not for corn. Farmers who use farm-saved seeds must follow a rigorous procedure and pay royalties to the variety's breeder. These fees vary, by country, in kind and amount. The seed industry makes repeated and concerted attempts to suppress farm-saved seed production. Some aid systems established in Common Agricultural Policy (CAP) even require the use of 'certified seeds' before aid is disbursed; farmers producing their own seeds lose their right to their subsidy (Anvar, 2008). It is in this context that the issue

\footnotetext{
${ }^{12}$ See the farm seed coordination site, http://cndsf.free.fr/. That would represent $50 \%$ of the straw cereal seed production, such as wheat, and $25 \%$ of the colza production. But it is almost non-existent for corn and beet. It must be noted though that the farmers who practice this activity buy seeds from the producers every five years or so, in order to benefit from the genetic progress.
} 
of self-production seed contamination, through gene flow from transgenic plants, is raised. Some states prohibit the use of farm-saved seeds because of the increasing risk of contamination within the context of co-existence; such a prohibition is an infringement to the farmer's wellestablished right.

\subsubsection{Labelling and traceability for a confidence economy}

Traceability refers to the techniques of identification and monitoring of products. These processes will be described, but we must understand that this is only one piece of the puzzle in building a confidence economy. The relationships of consumers, economic operators and public authorities with GMOs are complex, and can be simultaneously supportive and antagonistic. A policy of traceability must include the ability to identify, follow, choose and know that a product can be recovered in case of problem, in order to earn operator and consumer confidence. Once this trust is established, traceability shifts to a technical and political problem.

\subsubsection{Traceability as a technical issue}

Traceability is the ability to trace and follow a food, feed, food-producing animal or substance through all stages of production, processing and distribution. This is an important EU expectation, as exemplified by Regulation 178/02/ EC. Article 2 of Regulation 1830/2003 specifies that traceability applies to the following: products consisting of GMOs (e.g. a plant variety such as a tomato), products 'containing GMOs' (e.g. a can of tomato concentrate), feed produced from GMOs, and food produced from GMOs defined in Art. 3 as derived, in whole or in part, from GMOs but not containing or consisting of GMOs (e.g. oil produced from genetically modified soybean or sugar derived from GM sugar beet). Such products were initially excluded from the first labelling obligation (1997) and their further reintegration into items to be labelled could cause a dispute with the USA, in the context of the Technical Barriers to Trade Agreement. ${ }^{13}$ In the case of products consisting of, or containing, mixtures of GMOs, a declaration of use must be produced by the operator accompanied by a list of the 'unique identifiers', the internationally recognised GMO names. These products are traced specifically as consisting of, or containing, mixtures of GMOs (Art. 4-3). This task depends on the 'unique identifier' defined by the OECD and kept in the Community Register of Genetic Modification (Directive 2001/18 Art. 19,

\footnotetext{
${ }^{13}$ http://www.wto.org/english/tratop_e/tbt_e/tbt_e.htm.
}

Reg.1829/2003 Art. 3-4 of Reg.1830/2003, 5 and 17, Reg. 641/2004 Art. 3, Reg. 65/2004 Art. 2 and Art. 5; European Commission, 2003a, 2003b). The identifier, made of alphanumeric digits, is transmitted and samples are kept as proof all along the supply chain. In the event of genestacking in a single organism, an identifier specific to the stacking event must be developed (see the new maize 'SmartStax', which contains eight transgenes).

The tracing obligation applies only to authorised GMOs that have been intentionally placed on the market. Unauthorised GMOs released in European territory therefore constitute an acute problem.

There is no European labelling or tracing for: animals that have been fed with genetically modified feed, products obtained from these animals such as milk and its byproducts, meat and eggs, or products obtained from animals treated with genetically modified medicinal products (Rec. 16 of Reg. 1829/2003). Accordingly, the idea that zero tolerance should prevail in the EU has resulted in the current international discussion about LLP (Low Level Presence of GMO unapproved in a jurisdiction but approved in another one due to 'asynchronous approvals').

These labelling and traceability rules generate obligations for farmers, operators, service providers and ordering parties at any stage of production, processing and distribution (e.g. retail, distribution terminals, catering operations, factory canteens). A number of industrial firms specialised in the implementation of tracing systems (e.g. third party certification companies), and firms proposing schemes certifying the good quality of a given tracing system (public or private) have been created to satisfy these rules.

Authorities have several essential functions: to develop regulations, organise and undertake controls, register firms in order to check the theoretical conformity of the system implemented by that given firm (Rec. 19 of Reg. 183/2005, the Member State alone can have a complete overview of the supply chains, which is essential in the event of an incident), provide registers, records and certification of analysis laboratories, implement rapid alert systems (such as RASFF and RAPEX systems) and so on.

The Commission of European Communities has to comply with a number of obligations also, ranging from the development of texts harmonising industrial practices to the creation of multiple registers serving as probationary instruments useful in risk management including relevant information concerning GMOs not authorised in the European Community (Directive 2001/18 Annex IV, Art. 9-3 of Reg. 1830). Another obligation is the creation of a Community Register of genetically modified food and feed (Art. 28-1 of Reg. 1829/2003). 
In order to obtain compatible results, the task of harmonisation of detection methods and development of Certified Reference Material (CRM) is carried out by the Community Reference Laboratory, launched in 2003 by the Commission, part of the Joint Research Centre of the European Commission (BGMO unit and IRMM). The operators provide reference materials and quantitative identification methods. ${ }^{14}$ The CRL must 'validate the detection and the quantification methods' for GMOs, and evaluate the data submitted by the operators (Technical Guidance on sampling and detection of GMOs issued by the Commission no. 2004/787/CE [European Commission, 2004] that emphasises Regulation 1830 places the responsibility of inspections, controls and thus sampling and analysis techniques on Member States).

\subsubsection{Political aims of the traceability}

This technical framework creates a political instrument that seeks to reconcile various objectives: ensuring safety, building confidence in users and consumers, maintaining a well functioning market and creating opportunities for niche markets.

From a safety point of view, traceability has a role to play in the daily management of production in a quality assurance management system. This daily management could include: default localisation, intimate knowledge of the production process and, subsequently, the improvement of transparency (for producers and consumers). In the event of a crisis, traceability allows the monitoring, control and, when necessary, withdrawal of material. It is

${ }^{14}$ It must be noted that these regulation changes originate from the difficulties faced by EU funded FP5 Research programmes, because of the lack of cooperation of notifiers. Most of these research laboratories are also members of ENGL whose plenary sessions are attended by several EC officials. The proposed method must be validated by European authorities: 'Despite reiterated requests by the Commission, the Chinese authorities were unable to provide the Commission's Joint Research Centre (JRC) with control samples and a protocol of a detection method that were qualitatively and quantitatively appropriate for the JRC to validate the detection method used by the Chinese control authorities. [...] It is, therefore, the operator responsible for first placing food and feed on the market who should be under the duty to prove that they do not contain the contaminated products. [...] Due to the lack of a validated detection method and control samples of adequate quality and quantity - and in order to facilitate controls - the analytical report should be issued using the construct-specific method developed by D. Mäde et al. (2006)'. Commission decision of 3 April 2008, OJEU L 96/29 of 9.4.2008, pt.8, 12, 13. a set of techniques for managing a crisis by avoiding or containing economic and health consequences. A number of rules or law cases recognise the utmost importance of traceability in crisis management, particularly concerning recall of products within a potentially dangerous batch or those that are simply not authorised (e.g. the White Paper of 2000, Rec. 3 and Art. 1 of Reg. 1830/2003, the 'hygiene package' Alerts, Product Recalls, Embargos ${ }^{15}$ together with the 178/02/EC Regulation).

From a confidence economy point of view, traceability may induce significant economic costs, though those costs ought to be equally distributed among companies. However, traceability also permits some gains. When associated with labelling, it improves market transparency, which in turn builds confidence among users and opens avenues for segregated high value-added submarkets. It is also an important part of the good image of companies.

Having a traceability system in place generally induces numerous 'hidden' benefits, such as easier implementation of other tracing systems (e.g. allergens or mycotoxinproducing organisms). Rules and law cases recognise the link between traceability, safety and confidence (Reg. 178/2002). We can quote an interesting judgment on the 'legal basis' ${ }^{16}$ of a regulation instituting a harmonised system of identification, registration and labelling of bovine animals and meat. ${ }^{17}$ The court was asked: 'Does the Common Agricultural Policy or the protection of public health form the legal basis for the traceability process?' The Court gave preference to the Common Agricultural Policy: 'Still, the protection of health contributes to the good realisation of the common agricultural policy... especially when agricultural production is immediately dependent on its outflow towards consumers more and more preoccupied with their health' (pt. 49). The aim of the disputed regulation is to 're-establish bovine meat market stability after the unsettledness created by the BSE crisis, through improved transparency in production and commercialisation of the concerned products,

${ }^{15}$ Cf. analysis rice case in Deliverable 7.22 p. 22 et sv.

${ }^{16}$ Each text drafted by a European institution must state the legal foundation on which it is based: common agricultural policy, free movement of goods and so on. The fair determination of this legal basis is essential because the legality of the act is estimated in relation to the base chosen; on the other hand, the voting procedures are different from a legal basis to another, which explains the number of disputes.

${ }^{17}$ CJEC 4 April 2000, aff.C-269/97, Commission vs. Council, Rec. 2000, p. I-2257. 
especially with respect to traceability' (pt. 53). The Court also noted that 'subsequently, consumer confidence in beef meat and meat-based products will be encouraged' (pt. 55) and deduced that the primary objective of the regulation is to stabilise the market (pt. 59), a conclusion that is not contested by the fact that the system put into place will have positive effects on the protection of public health (pt. 61). The same idea can be found in French case law: 'the abusive use of the logo ("viande bovine française") by the accused and the resulting discredit caused to the association's initiative towards ensuring "traceability" of beef meat and thus restoring consumer confidence in the context of Bovine Spongiform encephalopathy crisis represents a personal and direct prejudice for the association' (Cass. Crim. 15 June 1999, No 98-83505).

Traceability and labelling help to differentiate markets from which professional and non-professional users can choose. Together, traceability and labelling increase the autonomy of users' choices through knowledge of the composition, origin and various characteristics of products. This autonomy of choice is the foundation of the co-existence project between organic, conventional and transgenic markets. ${ }^{18}$ But the European regulation does not provide rules for a GM-free label and leaves it up to the Member States to develop a definition of and strategy for 'GM-free' labelling. Ultimately, there should be four markets: organic, GMO-free, conventional and transgenic. This is particularly important for products well identified by consumers, such as poultry produced by small farmers or for cheeses, vines and so on with geographical indications.

\subsection{IMPORT SUPPLY CHAINS AND GMOs}

As animals fed with GM products or derivatives are not labelled in the EU, breeders importing soy beans to feed cattle are not generally concerned with whether or not they are GM-free (3.1). ${ }^{19}$ Nevertheless, some supply chains do

\footnotetext{
${ }^{18}$ In fact, as far as transgenic modifications are concerned, it looks like there may be only two markets: a market of products below $0.9 \%$ and a market of products above $0.9 \%$. But some Member States envision a new possibility; operators would have the right to opt for a GM-free label characterised by a threshold lower that $0.9 \%$. Compare the very complex system proposed by the CEES of the Haut Conseil des biotechnologies en France, http://www.ogm.gouv.fr/IMG/pdf/Recommandation CEES_sansOGM_cle0f8fef.pdf.

${ }^{19}$ Co-Extra Deliverable 7.22 title III: The organization of soja demand in feed chain, p. 60 et sv. The study was based on the particular of the Britain husbandry.
}

try to remain GM-free. It is not obvious whether the slow progress of 'GM-free' labelling will help (Section 23.3.2). The import of commodities does not depend on national laws, as commodities are regulated by professional legal dispositions (Section 23.3.3)

\subsubsection{Feed and indifference to GMOs}

Breeders are involved in integrated chains in which they do not control their livestock nutrition. Moreover they cannot, until now, value non-GMO production due to the lack of specific labelling for the animals and animals products. Most porcine and poultry production is indifferent to the GM feedstuffs issue because worries about prices and nutritional efficiency are the dominant factors of choice. This is true for standard production, in which GM feed is the standard. But it is also true for most of signs of quality. For example, French Pig Meat and the Product Conformity Certification Procedure insist only on traceability. It is true again for most (but not all) of the 'Red labels'; signs of quality that are highly valued in France. Very often, the label is concerned with the geographical origin of the meat, animal welfare and feed composition only in terms of percentage of cereals, oil seeds, leguminous plants and their sub-products.

\subsubsection{GM-free supply chains}

There are numerous GM-free supply chains, but they have a low economic impact. First and foremost, there are the organic supply chains: the "GMOs and products that are derived from GMOs or produced with GMOs are incompatible with the concept of biological production' (cdt.9). A product can be labelled as an organic product as long as it falls under the European threshold of $0.9 \%$, if 'operators can assume that no GMO product nor product derived from GMOs has been used in animal feed ... whenever those products do not bear any label . . . '(Art. 9.2). While the tendency is to chose the $0.1 \%$ threshold, nothing prevents the breeders from choosing a lower threshold. In that case, it is much more difficult to secure the chains, as the costs increase drastically when the prescribed threshold is decreased. The question is to determine whether it is possible to impose the $0.1 \%$ level on neighbours as a mandatory obligation, or whether it is up to organic farmers to protect themselves. The main trend is presently to put the onus on the neighbouring farm, when the organic farm existed first.

Second, there are the labels of origin. These concern some poultry, such as the 'Poulet de Bresse', many cheeses in France, and dairy products in Germany. 
Third, there are some voluntary actions which concern small-scale poultry production such as 'Coucou de Rennes' or 'Poulets de Loué' in France or distributor labels such as Carrefour, Iceland or McDonald's. For the pig, an example of a GM-free supply chain is the red label 'Argoat Pig Farmers' that relies on an industrialised company that sells meat, 'Le Gouessant' who processes feed (1 million tons of feed and 5 plants in Brittany), 4800 contracted members and a 383 million $€$ turnover. It owns the animals and coordinates production through a three-party convention between 'Le Gouessant', Bigard slaughterhouse and each producer. Another convention rules the relations between 'Le Gouessant' and a group called 'Les Fermiers d'Argoat' that brings together 60 producers. Pig production is regulated by provisions stated in a book of specifications that includes specific genetics, medium-sized farms and open-air breeding on straw. The feed includes at least $65 \%$ cereals, a rather low rate, and involves a 'GMO risk mastery' guaranteed by an accreditor, but not discussed by the partners. The breeder is free to choose his feed provider, yet has to appoint a provider who allows him to respect that obligation (PCR negative). The main issues discussed by the group are related to 'natural breeding mode' and animal welfare. Reference to GMOs is only found in the 'feed processor' book of specifications that obliges the latter to guarantee a 'feed that integrates the GMO risk mastery, i.e. the absence of GMOs in the final product up to a limit of fortuitous contamination limit, in compliance with the terms of the current regulations'. 'A control plan, with a PCR analysis method, will have to be established.' A list of the raw materials that could be used is fixed as an Appendix to the Contract (with the same legal status). It emphasises that the raw materials:

should not be issued from genetically modified seeds (traced chain or negative PCR), nor be in contact with GMOs at any time during their production or processing. The feed processor must check those guarantees with those providers. The feed processor must provide GMO noncontamination evidence from the raw materials reception stage to the delivery stage. That evidence is established according to the HACCP system principles. The feed processor must conduct a random survey of the finished product to be shipped.

It is a 'PCR negative system' (which generally means less than $0.01 \%$, the limit of detection) that is evaluated in the 'finished product' feed, and not in each step of the production chain, and represents the less expensive solution.
The second case began because the Carrefour Group wanted to develop, among its 'Carrefour quality chains', a pig chain wherein the feed was guaranteed GM-free. The legal ruling document is the chain convention. In 2006, Carrefour abandoned the total traceability process organised through the chain convention from Brazil (even though Soulès Caf's role was at least as essential). Carrefour switched to a policy that ignores upstream processes, and buys raw materials that are guaranteed to be less than $0.9 \%$ GMO from the unloading harbour. This choice is less costly, but is also particularly less difficult to organise as Carrefour acts only in France. The importer may encounter problems because of potential organisational defects in the feed producing countries. Indeed, segregation and traceability are provided for in the contracts, which are efficient yet costly, knowing that the non-GM importer will assume the total costs necessary to ensure segregation. ${ }^{20}$

An atypical example involves an ancient poultry race, 'La Coucou de Rennes'. ${ }^{21}$ In 1976, a couple of farmers, the 'Renault', began with the conviction that feeding animals is a sensitive issue in all respects. They criticised fish meal for the taste given to the eggs, animal flour for health, manioc given to pigs when it is used in human food in Africa, and more generally wanted to avoid 'productivist agriculture'. They developed a feeding system based in part on cereals grown on the farm and complemented by commercial feed (they negotiated a particular composition themselves). This animal variety was restarted from a few hens and a rooster. The producers' association was founded in 1997. They worked on a book of specifications by combining the experience of former farmers with non-traditional components that ensure better production profitability. The feed composition is detailed in the contract: original mixing maize, wheat, oats, barley, peas, beans, lupines, soybeans and then finished with whey. The contract expressly excluded manioc, animal fats, growth factors, antibiotics as growth promoters, fish meal, bone meal and, since 2003, GMOs. The association buys their

\footnotetext{
${ }^{20}$ None has regulations related to co-existence. Nevertheless, the regulations related to traceability are more or less numerous and hard. In the USA there is a traceability obligation linked to the law on bioterrorism; Brazil has rather precise regulations that specify the conditions that need to be fulfilled in order to get a non-GMO certificate; Sadia, the largest Brazilian chicken exporting company has excluded transgenic soya from its animal feed.

21 'La Coucou de Rennes' only communicates about non-GMO feed through the 'Slowfood' association (www.slowfood.fr).
} 
non-GM soya from a food manufacturer who has his own factory and provides food compounds upon request. This manufacturer has big customers, but also a large number of very small buyers working in direct sales. Each buyer negotiates its own formula separately. No clause specifies what happens in case of non-compliance. There are two stated reasons for this. For small buyers, the system runs on a combination of trust and state controls. Small buyers do not have the capacity for self-analysis and thus legal actions appear out of reach. There is some debate over whether certifications should be imposed on small buyers in the future and at whose cost. For suppliers, the system seems to work well; failures are very rare and it is not too costly to sell a defective product to a buyer indifferent to the GMO issue.

\subsubsection{Commodity supply contracts under the control of 'organisers ${ }^{\text {,2 }}$}

Europe imports most of its vegetal protein for cattle feeding. In these supply chains, there are strong convergences between supply and demand as they are established by operators, whom we shall call 'organisers', as market promoters. In fact, the decentralised supply by soy producers and farmers' decentralised demands do not come together of their own accord. Due to this double decentralisation, their meeting requires the involvement of middlemen. These middlemen organise the supply on one hand, the demand on the other and the logistics in-between, from fields in Latin America to operators in Europe. This implies a heavy network of silos, carriers and producers that require guaranteed funding, not so much by independent operators as by what are referred to as organisers. If there are some medium-sized operators, cooperatives or food producers, they are but the intermediate levels for the big traders (mainly Cargill, Bunge, ADM, Louis Dreyfus) and the major chemists and seed manufacturers who control access to funding. Contracts reflect this tendency, showing producers receiving chemical inputs and seeds for free, in exchange for returning part of the crop. They lose their freedom of choice regarding agronomical procedures and technologies. These organisers are on both sides of the Atlantic, working towards the highest convergence of mass supply and demand in order to facilitate international trade; the built soy complex lies on a strong homogeneity of the commodities involved.

In Argentina, the majority of farming is not performed by farmers, but rather by large companies to whom land owners rent their lands. 'Pool de siembra' live off

\footnotetext{
${ }^{22}$ For more details, see Co-Extra Deliverable 7.23 (synthesis).
}

investment funds and operate on a large scale on leased lands. Grobocopatel, for example, only owns $10 \%$ of the 150000 hectares that it exploits. Agrochemical companies (e.g. Monsanto, Dupont and Bayer) make up the second group of beneficiaries. They profit through the strong dependency that soy production has on new seeds, fertilisers and herbicides. The third sector is made up of five exporting companies that control $90 \%$ of sales (Cargill, Bunge, Dreyfus, Nidera and AGD).

Brazilians feel their country is particularly attractive to such multinational companies because these companies can dominate a large part of Brazilian soil and soy culture, in tandem with modernisation and professionalisation of Brazilian agriculture. In both Brazil and Argentina, a supply chain's freedom of seed choice is dominated by organisers who support input, equipment and infrastructure necessary for international trade.

Argentine and Brazilian legislations are also silent on the matter of traceability, which is only an issue for cooperatives and exporting companies with special contracts of 'identity preserved crops'. This places the importer in an uneasy position; they have quality obligations to fulfil for their buyers, but do not have full control of all the data upstream. Only through contracts can traceability and labelling be required upstream. There is a strong divergence concerning the legal organisation between supply (supply chains' upstream part), which is not subject to the obligation of traceability or sometimes even of labelling, and demand (downstream part), which is subject to these obligations. Two factors have reduced this degree of divergence, which is harmful for international trade. On the one hand the EU has practiced an open authorisation policy for marketing specific transformation events of animal nutrition for commercial ends, enabling exporters to sell their products without difficulty, while their European competitors were not allowed to grow these same varieties. On the other hand, the decision not to label either GMO-fed animals or their products (e.g. meat, milk, eggs) has made these mass imports possible without risking boycotts by consumers, who are not informed of the feed animals have consumed (1829/2003 regulation cdt.16). This practice has provided sufficient satisfaction to third world farmers, so reactions before WTO were very weak (one single hearing with no appeal; this compromise was clearly mentioned in the announcement made to signal the end of the dispute between Canada and Europe. A recent agreement has also been found between EU and Argentina). This implicit consensus is now changing with the increasing number of American and Argentine marketing authorisations of new 'transformation events' not approved in Europe, and the development of 
voluntary 'GMO-free' labelling on animal products (Meunier 2008; Stein and Rodriguez-Cerezo 2009).

Most of the imports go through standard-form contracts of international trade designed for standard soy and adapted for chains (e.g. SYNACOMEX, INCOGRAIN). The structure is redundant and common, and the specific description of the product is provided either in stereotyped product-cards, or if they are too specific, in specifications tailored to each operator. In this regard, the role of the Grain and Feed Trade Association (GAFTA) is essential (http://www.gafta.com). The association includes more than 80 standard contracts, representing up to $80 \%$ of the legal models used in the world for some products, and a whole arbitration system called 'GAFTA arbitration'. GAFTA covers all relevant areas of international trade policy including: WTO International Trade Negotiations, World Plant and Animal Health Legislation, Market Access and Customs issues and health and safety matters. GAFTA has a 'trade policy' service, which exerts strong influence on the legal decisions of both the private sector and public authorities.

GAFTA has recently applauded 'the decision within Codex Alimentarius to adopt a new tool (LLP) which would allow importing countries the opportunity to carry out a safety assessment on GM events that have been authorised elsewhere but not yet in the importing country which aims to minimise potential trade problems' in the same way as the EU. GAFTA 'is considering different options to find a "technical solution" to the EU zero tolerance policy which was expected at the end of last summer, but apparently not found. GAFTA is lobbying for a longterm solution in favour of the speeding up of EU authorisation processes and to achieve a sensible tolerance to continue imports of soy and maize and to minimise disruption to trade ${ }^{23}$. GAFTA also offers additional services such as insurance and, in a more general way, advice for compliance with the international trade law.

In fact, the aim of GAFTA's code of conduct is to facilitate exchange, by having a situation of relative uniformity along the contract chain and by working on improving convergence between supply and demand ('Guidance' for each identified issue, such as sampling, fumigation, con-

\footnotetext{
${ }^{23}$ http://www.gafta.com/index.php?page=trade_policy: it should be noted that in 1987, the Commission required the Association to change several of its operating rules to avoid being sentenced for illegal agreements, 87/44/EEC: Commission Decision of 10 December 1986 relating to a proceeding under Article 85 of the EEC Treaty (IV/29.036 - The GAFTA Soya Bean Meal Futures Association OJ 1987 L 019 p.18).
}

taminants, HACCP, traceability and labelling, EU Legislative Requirements, Recall and Withdrawal, etc., and may obtain the compliance certification by the NSF CMi Certification company).

The soy complex economics is embedded in contract networks. Sales contracts are rather well described (see the Deliverable 7.27 of Co-Extra), as are contracts of the services organising the chains: storage contracts in warehouses where contaminations are likely to occur, certification contracts, cargo grading, transport contracts and so on. A whole first part of the contract chain is determined by domestic law: sale of the farmer's production to his cooperative, contract of storage in the silo, transport contract and so on. This involves a number of significant consequences. If we take the example of Brazil, any domestic law contract between two Brazilian companies must necessarily use the Real as currency. The contract qualification and, for instance, the nature of the consumer who may or may not be tied to one purchase, are also determined by national law and by the courts of the judicial system. This will also be the case for storage contracts and certification contracts, for example.

Conversely, in international trade operations, parties will refer to 'traditional practices in international law' or maritime law, use master-contracts designed by professionals, and entrust disputes to a court of arbitration (and thus a private system of dispute settlement). For a long time, the shipping trade has given rise to "control and inspection' companies, which intervene at the points of departure and arrival of goods, ${ }^{24}$ and who are thus

\footnotetext{
${ }^{24}$ These companies are rarely studied despite their considerable importance for the fluidity of international trade. Acting most of the time on behalf of their shipping states to design what has been effectively shipped (devices of capital escape) or importing states, their operating mode has been the object of an agreement between WTO, ICC and IFIA (International Federation of Inspection Agencies), their international association. The IE was established in December 1995 by the General Council in conformity with Article 4 of the WTO Agreement on the inspection before shipment, which establishes an independent inspection procedure that will settle any disputes between exporters and inspection companies before shipment. It was applied after the ICC and IFIA had confirmed that the needed procedural and administrative prescriptions had been completed. The integral text of the General Council decision including the appendices relating to the IE rules of procedures and the calculations to be used in order to apply for an independent inspection may be obtained from the WTO Secretariat upon request, and are published on the WTO Internet website (Press/47, 1 May 1996, WTO Presshipment inspection body becomes operational).
} 
indispensable in ensuring the fluidity of the shipping trade. In fact, since the salesman is not present and often unknown to the customer, both must rely on representatives to be present for loading and unloading operations. Otherwise goods would only be assumed to be acceptable in both quality and quantity.

It is possible to assess strong limits of liability corresponding to the traditional practice of international trade by referring to the 'Recommended Terms and Conditions of Business 1999' of GAFTA following the work undertaken by IFIA (International Federation of Inspection Agencies, art.12). These strong limits of liability are to be found along the chain. In fact, whereas losses can be considerable at a given point of this chain (for instance in the case of a product distributed globally), each of the operators are only concerned with services within a limited cost (e.g. the company organising the traceability or providing certification). From an economic perspective, the pattern may not make them liable for loss at the very end, although their bad service performance may have contributed to the loss at some level. It is worth noting that there is no known arbitration sentence directly dealing with GMOs.

To what kind of market does the legal structure of this soy complex, as just described, correspond? The initial movement of goods depends on an administrative authorisation; it is not a free market. The second step is, on the contrary, a supply chain organised by contracts; it is a free market. Nevertheless, what we have observed is not so much the spread of economic freedom but the manifestation of the normative power of 'organisers'. It is the private sector which, with this practice, creates a 'tradition' referred to in the contracts. The private sector designs the recurring contractual figures and plays the role of legal advisor to the operators via professional federations as well as to public institutions such as Codex Alimentarius. It also interprets this whole device by letting go of anything alien to state rules, and by connecting contracts to 'conventions of international trade' and arbitral tribunals that are, themselves, composed of professionals.

Organising primary producers and end users imposes important consequences: strong economic and legal inequality between the 'organisers' and the 'organised' and placing fundamental importance of funding activities in favour of agriculture (seeds, fertilisers, machinery, etc.)

\subsection{A LIABILITY SYSTEM ADAPTED TO A CONTROVERSIAL TECHNOLOGY}

We have tried to devise an atypical liability system fit for GMOs destined for agriculture: a special law. The process will certainly be contested by the many legal experts who are against multiplying special systems, some operators who thrive on solutions in their favour or on the uncertainty from which they draw advantage and many public authorities (whether Member States or non-members of the European Union) who believe it preferable not to get involved in issues of liability or take a token level of action using a very limited 'Compensation Fund'. However, our proposed system will meet the approval of a segment of the general public and others who have been awaiting a clear solution to a problem they believe, rightly or wrongly, is quite special due to the controversial nature of GMOs. The novelty and uncertainty surrounding these technical objects have generated opposing attitudes: highly favourable versus highly critical. In order to overcome opposition, the European Union proceeded to impose chain co-existence, leading to many contamination opportunities and therefore to many liability assumptions and related redresses (Koch, 2007). Appealing to common law is highly complex and solutions are often uncertain, which is one among many causes behind the general rejection of GMOs. Combined with insurance companies' refusal to cover damages, the inadequacy of liability law is considered an unfavourable signal, as is regularly demonstrated by surveys, citizen conferences and the French 'Grenelle de l'environnement'. Thus, we propose a special law.

The request for a visible and comprehensible process logically leads to the idea of an institution which would understand the motivation of all players and control minimum technical and economic data. Ideally, it should be composed of judges with some experience in liability law and of a small number of scientists and other interested parties. It could be a kind of compensation fund extended to all liability issues and not confined to contaminations in the field. This panel's decisions, which could be made quickly, would of course be subjected to a range of judicial settlements.

\subsubsection{Damage to repair}

If there were a special law, it would be worth considering all malfunctioning aspects of co-existence that might occur. With regard to GMOs, these problems would involve mainly economic damage, in its broadest sense. Two ideas predominate. On one hand, some forms of damage are diffuse and of a collective nature and are hardly perceived nowadays (e.g. insect resistance or herbicide tolerance acquisition) while others are individual (e.g. contamination of a field). On the other hand it is important to consider prejudices that may occur in all chains and in the agronomic system as a whole and not, as most states have done, to just offer a solution specific 
to field contaminations. There are many potential prejudices to repair. We note the following:

- Harm incurred by what we call agro-systems: resistance acquisition by weeds or insects, failure of pollinating insects, herbicide concentration in rivers, groundwater or land.

- The deceptive nature of performance promises to GM farmers.

- Losses incurred by operators of non-GM chains (i.e. price decrease, market loss, certification loss, penalties in case of neglecting to label, etc.), or even by the chain itself (e.g. obligation to shut down a chain, see for instance Deliverable 7.23.2 of Co-Extra, Belgian case).

- Losses incurred by non-GM plant breeders whose seeds were contaminated, given that their very corporate purpose rests on their ability to product non-GM products.

\subsubsection{Liability for fault versus no-fault liability}

We have evaluated the idea of both liability for fault and no-fault liability, in the context of co-existence of agricultural supply chains.

No-fault liability has the advantage of instilling confidence in the public and operators likely to be victims of contamination, of facilitating compensation for damage, of distinguishing between the responsible (economic dimension) and the culprit (moral dimension), of directing the first occurrence of liability toward those who are most active in implementing technology. Nevertheless, we have not excluded liability for fault when an operator breaks co-existence rules, whether intentionally or not.

Some legislation has already instituted no-fault liability for some kinds of damage. This is how, for the purpose of settling conflicts, many Member States have decided to create full-right liability to compensate for field contaminations. This idea is worth applying to the whole chain, while concentrating liability claims on some large organisers of GMO chains who could later take legal action against the operators. These operators could be the inventor of the gene, the plant breeder, the seed producer, the trader or the agro-industrial company. As permit holders and leaders in international trade, these operators fill strategic and highly visible positions. They also capture most of the added value. We would then be in the realm of strict liability (relieves the victim from proving fault) and exclusive liability (legal channelling of liability, regardless of the cause of accident on the three types of organisers).

Liability for fault is when an operator, bound by a definite obligation, does not fulfil this obligation. This is the case of the GMO farmer who does not follow good farming practices, of the third party certification company that does not follow the planned sampling protocol or of the carrier who does not clean the truck. We believe it is important to maintain such liability, combined with heavy penalties, in order to persuade professionals to follow the rules specific to co-existence.

Both types of liability already exist from the mere fact of common law. But they are not organised into a coherent structured system. The presence of a compensation fund that centralises all issues of liability would offer this coherence. This could be done through the designation of someone in charge of fast settlement and through the later distribution of tasks according to the contribution of each player in the damage and to the faults committed.

\subsubsection{Those that are liable}

If we follow the rationale behind these early indications, those individuals who are liable stand out clearly.

GMO notifiers, as permit holders, and plant breeders who use the authorised genetic event, should be made liable on the basis of risk, for diffuse or individual damage resulting from the working of the gene they have marketed and distributed including: herbicide tolerance or insecticide resistance acquisition by weeds or insects, failure of pollinating insects, deceptive nature of promised performances, field contaminations or herbicide concentration in rivers, groundwater or land (though it is worth observing that the cause and effect link may not always be easy to demonstrate). This would not prevent legal action against a farmer who may not have followed good farming practices. However, there is no reason for making farmers liable for all dysfunction in the non-GM chains. In this case, the major operators are either the traders for all dysfunctions upstream from the port of unloading, or the various industrialists involved in dysfunctions downstream from the port of unloading (animal feed, readymade dishes, canned corn, dairy industry, etc.). It is possible to take legal action against another operator who has failed to meet his obligation.

Finally we have evoked Member States' liability. Having established rules of good practice, they would be held accountable for over-lenient rules harming conventional farmers or for too rigorous rules harming GM farmers. In addition, they may commit faults by not performing sufficient inspections.

More difficult to justify, in spite of its importance, would be the idea that permit holders and Member States should be held co-liable for diffuse damage. Co-liability results from a normal functioning of the marketed gene 
with an absence of planning likely to allow successful management of the state of rivers or resistance acquisition; these are well known occurrences that only require long term vision of GMO cumulative effects.

But at any other level, there may be small operators with obligations that must be met. Problems with the quality of laboratory tests, the location of apiaries, sharing of information by non-GM farmers, and designing certifications and traceability may all lead to disproportionate damage compared to the value of the provided service. These small operators should be penalised. In practice their liability is carefully, but rightly, limited.

A few reminders: accepting exclusion of the development risk may seem legitimate in the presence of unfamiliar and unsuspected occurrences. But in the field of GMOs many risks have been envisioned since the earliest stages of the technique. Articles, with warning signals, were published. It is therefore necessary to provide a few guidelines to allow better delineation of risk development in the context of a contested technology with much, though marginal, scientific criticism. The Swiss law is pushing for the extension of prescriptions, and that could be fair to such an innovating technology that generates medium-term uncertainties. The resistance of insurance companies could, as suggested above, be subdued by fund deposit systems.

\subsection{CONCLUSION}

It is not an easy task to present five years of legal work in a field which has so far only produced general principles of law and some guidelines or syntheses of existing legal frames. We will specifically retain the originality of the coexistence project, which allows the use of a new technology without putting aside other pre-existing technologies. Running a farm according to one's own choice - organic, conventional or transgenic production - certainly conforms to the freedom of trade and industry. However, it entails high levels of constraints for all producers and a strange relationship between constraint and freedom. In fact, we could argue that more constraints equal more freedom or, from a chronological viewpoint, it would appear that in order to ensure freedom, constraints must be instituted.

This is a new form of governance of techniques, proposed in a context of protest, based on a new appreciation of freedom of trade and industry as well of freedom of consumers. Technological pluralism can be perceived as a compromise between groups with opposing views. On one hand, there are large commodity movements, legally organised by major trading companies who structure the flow of commodities through contracts and settle disputes by arbitration procedures. On the other hand are small supply chains organised by distributors, restaurants, plant breeders and so on around a few quality characteristics and appropriate labels. In opposition to what is planned by the European Community, it seems to us that a specific liability law should be set up in order to respond to these technological controversies. Only the combination of these different elements can, perhaps, allow the establishment of a 'confidence economy'.

\section{REFERENCES}

Anvar S. 2008. L'emprise d'un modèle économique dominant sur une réglementation sectorielle. Thèse Paris1 ( $\mathrm{PhD}$ thesis), pt.235, http://tel.archives-ouvertes.fr/docs/00/33/ 57/66/PDF/20081030_These_Anvar_Tome_1_Semences_ et_droit.pdf [accessed 1 May 2012].

Bellivier F. et Noiville C. 2009. La bioéquité - Batailles autour du partage du vivant. Autrement Frontières. Paris.

Davison J. and Bertheau Y. 2007. EU regulations on the traceability and detection of GMOs: difficulties in interpretation, implementation and compliance. $\mathrm{CAB}$ reviews. Perspectives in Agriculture, Veterinary Science, Nutrition and Natural Resources 2007, 2(077): 14 p.

de Candolle A. 1883. Origine des plantes cultivées. Germer Baillière, Paris.

ETC Group. 2008. Patenting the 'Climate Genes' . . a and capturing the climate agenda http://www.etcgroup.org/en/ [accessed 1 May 2012].

European Commission. 1990. Council Directive 90/220/EEC of 23 April 1990 on the deliberate release into the environment of genetically modified organisms. Official Journal of the European Communities, L 117: 15-27.

European Commission. 1994. Council Regulation 2100/94 of 27 July 1994 on Community plant variety rights, modified by Regulation 2506/95 of 25 October 1995, Official Journal of the European Communities, L 258: p. 3.

European Commission. 1997. Regulation (EC) No 258/97 of the European Parliament and of the Council of 27 January 1997 concerning novel foods and novel food ingredients. Official Journal of the European Communities, L 043: 1-6.

European Commission. 2001. Directive 2001/18/EC of the European Parliament and the Council of 12 March 2001 on the deliberate release into the environment of genetically modified organisms and repealing Council Directive 90/220/EEC. Official Journal of the European Communities, L106: 1-38.

European Commission. 2001. Directive 2001/18/EC of the European Parliament and of the Council of 12 March 2001 on the deliberate release into the environment of genetically modified organisms and repealing Council Directive 90/220/, Official Journal of the European Communities, L 106: p. 1 (for traceability, see especially Rec.42, Art. 4, Art. 4-6, Annexes III and IV).

European Commission. 2002. Regulation (EC) 178/2002 of the european Parliament and of the council of 28 January 
2002 laying down the general principles and requirements of food law, establishing the European Food Safety Authority and laying down procedures in matters of food safety, Official Journal of the European Communities, L 31:/1, See especially articles 3-15 and 18 .

European Commission. 2003a. Commission Recommendation of 23 July 2003 on guidelines for the development of national strategies and best practices to ensure the coexistence of genetically modified crops with conventional and organic farming (notified under document number $\mathrm{C}(2003)$ 2624). Official Journal of the European Communities, $L$ 189: 36-47.

European Commission. 2003b. Regulation (EC) No 1829/2003 of the European Parliament and of the Council of 22 September 2003 on genetically modified food and feed. Official Journal of the European Union, L268: 1-23.

European Commission. 2003c. Regulation (EC) No 1830/2003 of the European Parliament and of the Council of 22 September 2003 concerning the traceability and labelling of genetically modified organisms and the traceability of food and feed products produced from genetically modified organisms and amending Directive 2001/18/EC. Official Journal of the European Communities L268: 24-28.

European Commission. 2004. European Commission recommendation 787/2004 of 4 October 2004 on technical guidance of sampling and detection of GMO and material produced from GMO as or in products in the context of Regulation (EC) no. 1830/2003, Official Journal of the European Union, L 348: p. 18.

European Commission. 2007. Council Regulation (EC) 834/2007, 28 June 2007 on organic production and labelling of organic products and repealing Regulation (EEC) $\mathrm{n}^{\circ} 2092 / 91$, Official Journal of the European Union, L 189:/1 p. 1.

European Commission. 2009. Report from the Commission to the Council and the European Parliament on the coexistence of GM crops with conventional and organic farming, SEC (2009) 408, C(2009) 153 final, Brussels, 02/04/2009.

European Commission. 2009. Report from the Commission to the Council and the European Parliament on the coexistence of genetically modified crops with conventional and organic farming (SEK(2009) 408). COM/ 2009 / 0153 final. 12 p. Available at: http://eur-lex.europa.eu/LexUriServ/ LexUriServ.do?uri=COM:2009:0153:FIN:EN:PDF [Accessed 1 May 2012].

Gottweis H. 1998. Governing molecules: The Discursive Politics of Genetic Engineering in Europe and the United States. MIT Press, Cambridge, MA, USA.

Harlan J.E. 1987. Les plantes cultivées et l'homme. C.I.L.F./ A.C.C.T. Paris.

Haudricourt G. and Hédin L. 1987. L'Homme et les plantes cultivées. A.M. Métaillié, Paris.
Hermitte M.A. 2006. Les zones sans plantes génétiquement modifiées - l'illégalité comme stratégie juridique. J. international de bioéthique,17(3): 39 .

Hermitte M.A. 2007. La fondation juridique d'une société des sciences et des techniques par les risques et les crises. In: C. Burton-Jeangros and V. November: Face au risque, Georg, L'Equinoxe, Paris. pp. 29-71.

Hoisington D., Khairallah M., Reeves T., Ribaut J-M., Skovmand B., Taba S. and Warburton M. 1999. Plant genetic resources: What can they contribute toward increased crop productivity? Proc. Natl. Acad. Sci. 96: 5937-5943.

Koch B. (ed.). 2007. Economic damage from GMO admixture in non-GM products: liability and compensation schemes. Conference 'Co-existence of genetically modified, conventional and organic crops - freedom of choice' from April 2007, Springer Wien-New York; and T.K. Epprecht: Did biotechnology regulation come to a conclusion? An Insurers' perspective. In: Bernhard A. Koch (ed.) Liability Issues and Redress Mechanisms in the Food and Feed Supply Chains, Co-Extra Deliverable D.7.3.

Lezaun J. 2006. Creating a new object of government: making genetically modified organisms traceable, Soc. Stud. Sci., 36(4): 499-531, www.sagepublications.com [accessed 1 May 2012].

Levidow L. and Boschert K. 2007. Co-existence or contradiction? GM crops versus alternative agricultures in Europe. Geoforum 01 001; The 'Law of Alliance' is that Levidow et al. term as 'scientized politics', but is this truly 'politics'?

Levidow L., Murphy J. and Carr S. 2007. Recasting 'substantial equivalence': transatlantic governance of GM food', Science, Technology and Human Values 32(1) 26-64.

Meunier E. 2008. INF'OGM Actu décembre 2008 no. 15.

Meynard J.M. and Jeuffroy M.H. 2006. Quel progrès génétique pour une agriculture durable? Dossier de l'environnement de l'INRA, 30: 15.

Noisette C. 2008. Brevets et changement climatique, INF'OGM Actu no.12 - September 2008; Un soja conventionnel qui résiste à la sécheresse, Inf'OGM Actu no.19 April 2009.

Piñeyro-Nelson A., Van Heerwaarden J., Perales H.R., Serratos-Hernández J.A., Rangel A., Hufford M.B., Gepts P., Garay-Arroyo A., Rivera-Bustamante R. and AlvarezBuylla E.R. 2009. Transgenes in Mexican maize: molecular evidence and methodological considerations for GMO detection in landrace populations. Mol. Ecol., 18(4): 750-761.

Stein A.J. and Rodriguez-Cerezo E. 2009. The global pipeline of new GM crops, implications of asynchronous approval for international trade. JRC Scientific and technical reports. Vavilov N. 1951. The Origin, Variation, Immunity and Breeding of Cultivated Plants. Selected Writings. Ronald Press, New-York. 
